\title{
Study of Chaco Basin thickness with receiver function
}

Pedro Moraes, Undergraduate student in University of São Paulo

Copyright 2019, SBGf - Sociedade Brasileira de Geofísica

This paper was prepared for presentation during the $16^{\text {th }}$ International Congress of the Brazilian Geophysical Society held in Rio de Janeiro, Brazil, 19-22 August 2019.

Contents of this paper were reviewed by the Technical Committee of the $16^{\text {th }}$ International Congress of the Brazilian Geophysical Society and do not necessarily represent any position of the SBGf, its officers or members. Electronic reproduction or storage of any part of this paper for commercial purposes without the written consent of the Brazilian Geophysical Society is prohibited.

\section{Abstract}

We present preliminary results of inversion of receiver functions for $P$ waves, calculated from seismic events registered in stations on Chaco Basin, in Argentina and Paraguay. We also present preliminary velocity models in function of depth to estimate the geological structure of sedimentary layers.

\section{Introduction}

Chaco Basin (CB) is located in meridional region of South America, extending for $700000 \mathrm{~km}^{2}$ from northeast of Argentina until parts of Paraguay, Uruguay and Rio Grande do Sul state, in Brazil. It was formed by sediments from Andes, that were deposited there because of the subsidence initiated about $500 \mathrm{My}$, in Eopaleozoic. The subsidence was not continuous, intercalating with uplifting phases. CB sedimentary sequences extend until Quarternary. The Neopaleozoic and Mesozoic sequences are shared with Paraná Basin (PB), such as the basaltic lavas of Serra Geral formation (Kokogian, et.al., 1999; Dragone, 2013).

Assumpção et al. presented in 2013 a crustal model of South America, based on compiled data of refraction seismic experiments, receiver function analysis and surface waves. They attributed a crustal thickness of $35 \mathrm{~km}$ in the CB region, but the lack of seismic stations decreases the interpolation reliability. In 2014 the Seismology Center of the Institute of Astronomy, Geophysics and Atmospheric Sciences of the University of São Paulo (IAG-USP), in a project of Fundação de Amparo à Pesquisa do Estado de São Paulo (FAPESP), deployed a temporary network of stations, the XC network, that operated until 2018 and included the SCCA, TICA, and VACA stations, in Argentina, and FDPY and PAPY in Paraguay (Figure 1).

The general objective of this work is to establish a velocity model of sedimentary layers of $C B$, that is one of the least studied in the continent, using the receiver function method and encompassing the XC network. The specific objecttive is to present new estimates of basin thickness.

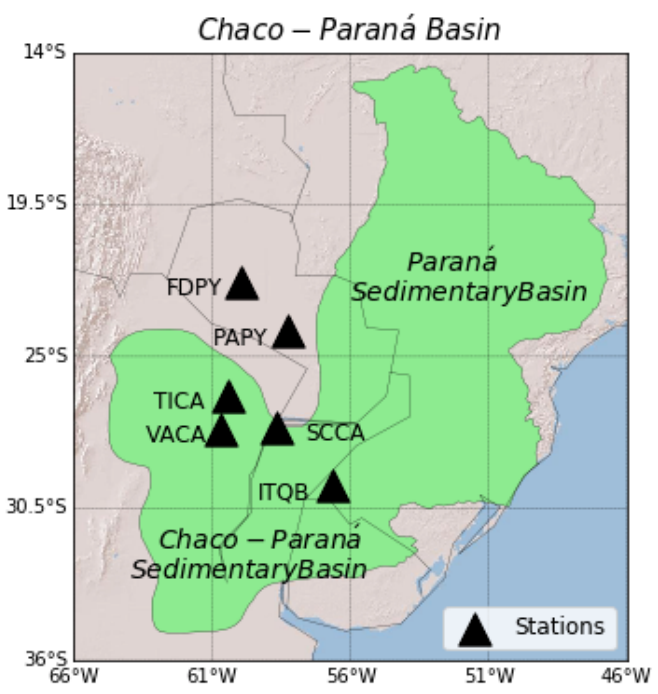

Figure 1 - Location of Chaco Basin, southwest location of Paraná Basin. The triangles indicate the stations used in this study.

\section{Method}

Receiver function (RF) is a widely used method in Seismology to determine crustals models. The components of a seismic register can be represented as convolutions:

$$
\begin{aligned}
& \mathrm{Z}(\mathrm{t})=\mathrm{S}(\mathrm{t}){ }^{*} \mathrm{I}(\mathrm{t}){ }^{*} \mathrm{H}_{\mathrm{Z}}(\mathrm{t}) \\
& \mathrm{R}(\mathrm{t})=\mathrm{S}(\mathrm{t}){ }^{*} \mathrm{I}(\mathrm{t}){ }^{*} \mathrm{H}_{\mathrm{R}}(\mathrm{t}) \\
& \mathrm{T}(\mathrm{t})=\mathrm{S}(\mathrm{t}){ }^{*} \mathrm{I}(\mathrm{t}){ }^{*} \mathrm{H}_{\mathrm{T}}(\mathrm{t})
\end{aligned}
$$

where " * " denotes convolution; Z R and T are, respecttively, the vertical, radial and transversal components; $S$ is the source signature, $I$ is the instrument response and $\mathrm{H}$ is the geological response in the components. Considering that a $\mathrm{P}$ wave arrives with low incidence angle, we have:

$$
\begin{aligned}
& \mathrm{H}_{\mathrm{T}}=0 \\
& \mathrm{H}_{\mathrm{Z}}=\delta
\end{aligned}
$$

Where $\delta$ is the Delta of Dirac. So, we can rewrite the equations (1), (2) and (3) as:

$$
\begin{gathered}
\mathrm{Z}(\mathrm{t}) \approx \mathrm{S}(\mathrm{t}){ }^{*} \mathrm{I}(\mathrm{t}) \\
\mathrm{R}(\mathrm{t})=\mathrm{S}(\mathrm{t}){ }^{*} \mathrm{I}(\mathrm{t}){ }^{*} \mathrm{H}_{\mathrm{R}}(\mathrm{t}) \\
\mathrm{T}(\mathrm{t})=0
\end{gathered}
$$


Rearranging these equations, we have the RF for $\mathrm{P}$ waves:

$$
\mathrm{H}_{\mathrm{R}}(\mathrm{t})=\mathrm{R}(\mathrm{t}) /\left(\mathrm{S}(\mathrm{t}){ }^{*} \mathrm{I}(\mathrm{t})_{-} \approx \mathrm{R}(\mathrm{t}) / \mathrm{Z}(\mathrm{t})=\mathrm{FR}(\mathrm{t})\right.
$$

Where the division indicates deconvolution. $F_{R}(t)$ is the $\mathrm{RF}$, that represents an approximation of $S$ wave response under the station for a $\mathrm{P}$ pulse. In RF, the first pulse is interpreted as the direct $P$ wave and each next pulse as an arrival of a conversion of $\mathrm{P}$ to $\mathrm{s}$, either a direct phase or a reverberation (Ammon, 1991; Owens et.al., 1984; apud. Bianchi, 2008).

The used data were collected by the XC network between 2014 and 2018 and we selected events with magnitude higher to equal 4.5 and depth equal or greater than 450 $\mathrm{km}$ (Figure 2). The choice for deep events is to decrease the variation in signal caused by the passage of waves through the layers of the asthenosphere, so that much of its path is in the lower mantle. We also used events of ITQB station, of BL permanent network, in the boundary of $\mathrm{CB}$, in Rio Grande do Sul. For the approximation of equation (6) to be maintained, it is necessary to assume an almost vertical incidence. So, it is preferable to use teleseism (distance between $30^{\circ}$ and $90^{\circ}$ ), because the arrival is more vertical.

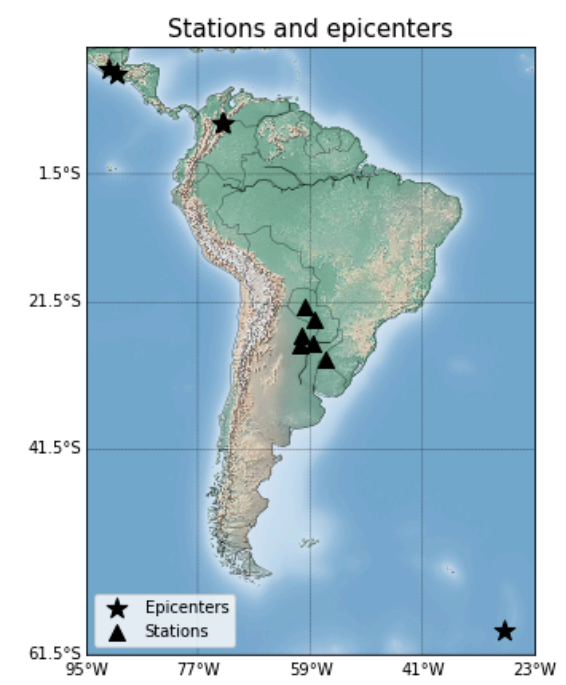

Figure 2 - Location of the stations and the used events. Most part of them happened in the same region of Central America and they overlap each other on the map.

We obtained RFs for the stations using the iterative process of deconvolution in time-domain proposed by Ligorría and Ammon (1999) that, although it needs high quality data, it is a simple way to estimate a RF without the need of relate to water level and smoothing and damping in time-domain. The program used, of Herrmann package (2013), uses a Gaussian filter factor that controls the band width. To emphasize more superficial layers, we applied the deconvolution with Gaussian factor of 5, 7.5 and $25 \mathrm{~Hz}$ in XC data and 5,15 and $25 \mathrm{~Hz}$ in $\mathrm{BL}$, obtaining high frequency RFs.
The average of the RF traces were inverted to obtain velocity models, but as it is an inverse problem with a non-unique solution, the ambiguity had to be eliminated with joint inversion with surface waves dispersion. The dispersion data were obtained in other study in IAG-USP (Shirzad et al., 2019).

\section{Preliminary Results}

The inversion of ITQB RF presented RMS of $0.032,0.024$ and 0.032 , respectively for $\mathrm{RF}$ with 5,15 and $25 \mathrm{~Hz}$ Gaussian factor (Figure 3). The velocity model (Figure 4) shows the basement about $1.4 \mathrm{~km}$ deep. It is known that this station was installed on basalt, that appears in the model as a high velocity layer with about $100 \mathrm{~m}$ of thickness. The difference of amplitude between data and inversion in the first pulse (in 15 and $25 \mathrm{~Hz}$ Gaussian factor Rf) can indicate that Vs attenuates more smoothly as it approaches the surface then what the model predicts. That is, Vs at the surface layer should be even lower.

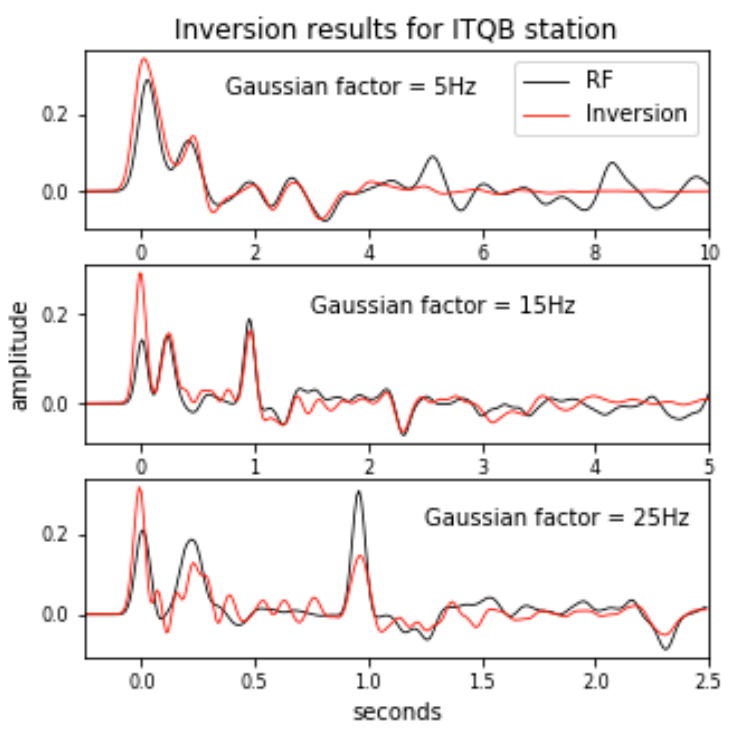

Figure 3 - inversion for ITQB of RF calculated with three Gaussian factor: 5,15 and $25 \mathrm{~Hz}$. RMS of $0.032,0.024$ and 0.032 , respectively.

The inversion of SCCA RF presented RMS of 0.071 , 0.066 e 0.049 , respectively for RF with $5,7.5$ and $15 \mathrm{~Hz}$ Gaussian factor (Figure 5). The velocity model (Figure 6) indicates a sedimentary layer of $700 \mathrm{~m}$ followed by a package of more consolidated sedimentary rock that extend until $4.6 \mathrm{~km}$ deep, where is the basement. 


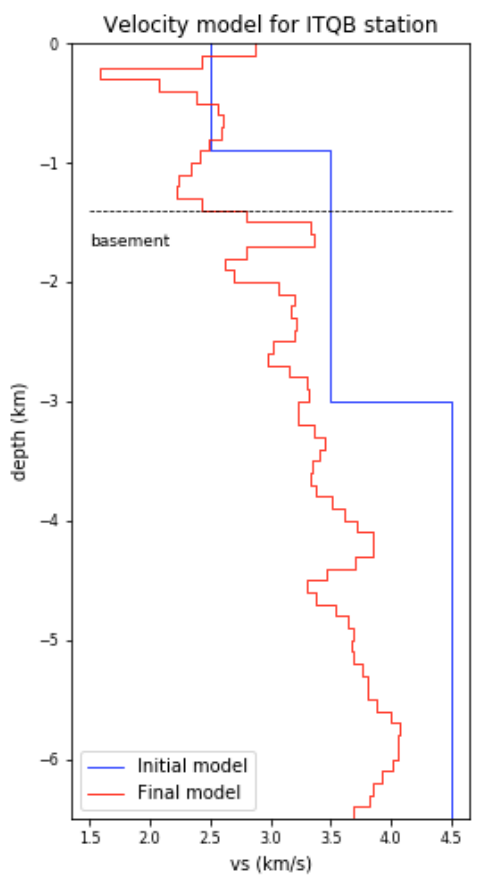

Figure 4 - Velocity model for ITQB station, with basement at $1.4 \mathrm{~km}$.
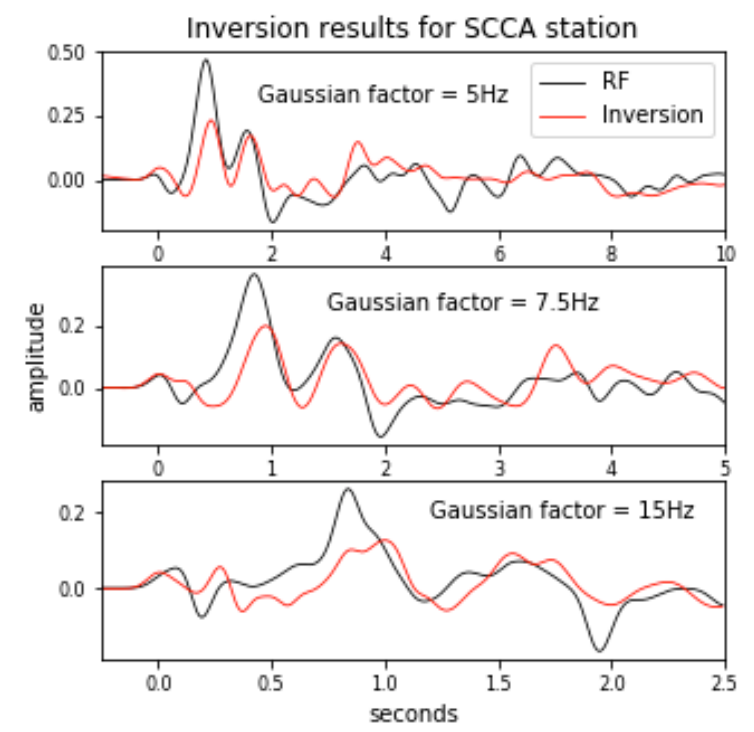

Figure 5 - inversion for SCCA of RF calculated with three Gaussian factor: 5,15 and $25 \mathrm{~Hz}$. RMS of $0.071,0.066$ e 0.049 , respectively.

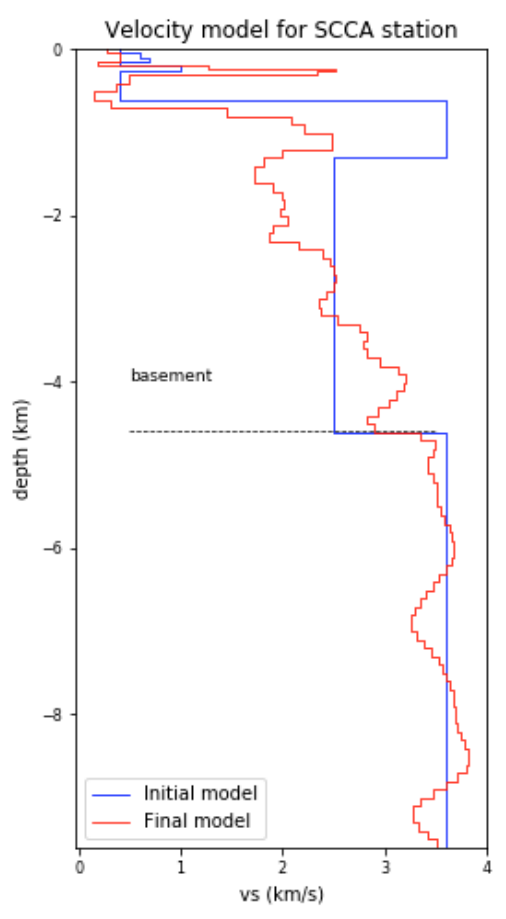

Figure 6 - Velocity model for SCCA station, with basement at 4.6 $\mathrm{km}$.

\section{Preliminary Conclusions}

The models presented basin thickness close to expected. The inversion are still relatively unstable and may need improvements to be more precise to detail the sedimentary layers.

The results presented in this work are preliminary and new models should be estimated, improving results of ITQB and SCCA stations and estimate thickness for the other stations.

\section{References}

AMMON, C. J. The isolation of receiver effects from teleseismic $p$ waveforms. Bulletin of the Seismological Society of America, v. 81, n. 6, p. 2504-2510, dez. 1991. In BIANCHI, M. B. Variações da estrutura da crosta, litosfera e manto para a plataforma Sul Americana através de funções do receptor para ondas P e S. 2008, 134 p. Tese - Universidade de São Paulo, São Paulo, 2008.

ASSUMPÇÃO, M.; FENG, M.; TASSARA, A.; JULIÀ, J. Models of crustal thickness for South America from seismic refraction, receiver functions and surface wave tomography. Tectonophysics, 2013.

BIANCHI, M. B. Variações da estrutura da crosta, litosfera e manto para a plataforma Sul Americana através de funções do receptor para ondas P e S. 2008, 134 p. Tese - Universidade de São Paulo, São Paulo, 2008. 
DRAGONE, G. N. Estrutura crustal da bacia do ChacoParaná a partir de dados gravimétricos. 2013, 94 p. Dissertação - Universidade de São Paulo, São Paulo, 2013.

HERRMANN, R. B. (2013) Computer programs in seismology: An evolving tool for instruction and research, Seism. Res. Lettr. 84, 1081-1088.

KOKOGIAN, D. A., et.al. Los depósitos continentales triásicos. Geología Argentina, 1999. Buenos Aires, Instituto de Geología y Recursos Minerales. Anales n² 29, p. 377.

OWENS, T. J.; ZANDT, G.; TAYLOR, S. R. Seismic evidence for an ancient rift beneath the cumberland plateau, tennessee: A detailed analysis of broadband teleseismic p waveforms.Journal of Geophysical Research, v. 89, n. B9, p. 7783-7796, 1984. In BIANCHI, M. B. Variações da estrutura da crosta, litosfera e manto para a plataforma Sul Americana através de funções do receptor para ondas $P$ e S. 2008, 134 p. Tese - Universidade de São Paulo, São Paulo, 2008.

SHIRZAD, T.; M. ASSUMPÇÃO; B. COLLAÇO, 2019. Crustal structure using ambient seismic noise in WestCentral Brazil. $3^{\text {rd }}$ Symposium of Brazilian Seismology, Vinhedo, SP, Brazil, Abstract, 14-17 April 2019. 